\title{
Are All 5-HT3 Receptor Antagonists the Same?
}

\author{
Robert McNulty, PharmD, Columbus, Ohio
}

\author{
Key Words \\ Ondansetron, granisetron, dolasetron, palonosetron, nausea, \\ vomiting, chemotherapy
}

\begin{abstract}
The 5-hydroxytryptamine type 3 (5-HT3) receptor antagonists have become the cornerstone for preventing and treating chemotherapy-induced nausea and vomiting. Four 5-HT3 antagonists are commercially available in the United States, and numerous reports have been published comparing 2 or more agents. The studies ranged from randomized, double-blinded to open-label or retrospective trials; included chemotherapy-naïve and -non-naïve patients; and covered a range of doses and routes of administration with and without concomitant steroids, for preventing and treating nausea and vomiting after highly and moderately high emetogenic chemotherapy. With few exceptions, the studies uniformly show an equivalent efficacy rate and side effect profile among the various agents at equivalent doses. This article reviews the pharmacology of the class for insight into minor differences among the agents that could possibly influence drug selection for certain patients, and considers data on the absorption, half-life, metabolism, and receptor activity. Clinical trials support the claim of various guidelines that the 5-HT3 receptor antagonists are therapeutically similar in safety and efficacy, particularly because the current best practice for preventing nausea and vomiting after highly and moderately high emetogenic chemotherapy is a combination of a 5-HT3 antagonist, steroids, and aprepitant. (JNCCN 2007;5:35-43)
\end{abstract}

In 1991, the U.S. Food and Drug Administration (FDA) approved ondansetron, the first commercially available serotonin receptor antagonist for the prevention and treatment of chemotherapy-induced nausea and vomiting

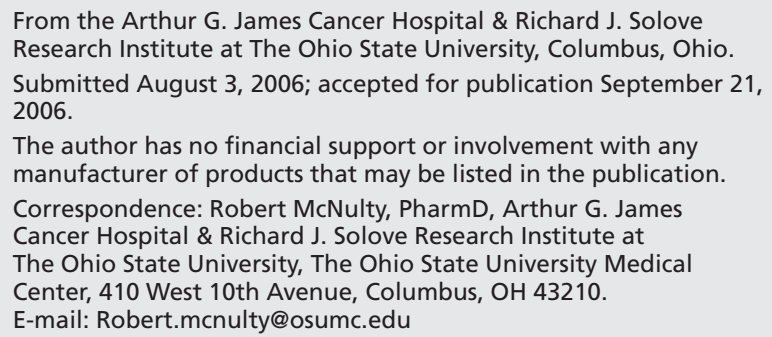

(CINV). In less than 2 decades, the serotonin receptor (or 5-hydroxytryptamine type 3; 5-HT3) antagonists have become the cornerstone for the prevention of CINV. In the United States, four 5-HT3 antagonists are available: ondansetron, granisetron, dolasetron (a prodrug for hydrodolasetron), and a second-generation 5-HT3 antagonist, palonosetron.

The National Comprehensive Cancer Network (NCCN) guidelines, ${ }^{1}$ American Society of Clinical Oncology (ASCO) guidelines, ${ }^{2}$ and Cancer Care Ontario practice guidelines ${ }^{3}$ currently describe these agents as equivalent in efficacy and lack of toxicity and therapeutically interchangeable after equipotent dosing. The literature supporting this conclusion is extensive and involves more than 49 reports comparing 2 or more agents directly in the clinical setting. The most reliable end point for evaluating studies of antiemetic regimens is the incidence of emesis. Nausea tends to occur at a higher incidence than vomiting, and vomiting does not usually occur without nausea. Nausea is a symptom that can be gauged only by the patient but may be indirectly quantified using questionnaires and visual reporting tools. The reported perceptions of nausea correlate well with the data from the combination of emesis incidence and use of rescue medications. By defining a complete response as no emetic episodes and no use of rescue medications after the administration of chemotherapy, data can be measured reliably with a high degree of accuracy.

Table 1 summarizes the clinical trials of 5-HT3 antagonists for CINV. Most trials compare ondansetron and granisetron, and a range of doses using both the oral and intravenous routes were studied. Corticosteroid steroid use was another variable across the different trials. Prophylaxis was used prior to administration of moderately high and highly emetogenic regimens. Some trials also investigated antiemetic therapies for preparatory regimens for bone marrow transplant. Single-day chemotherapy 
and multiday chemotherapy were studied. Study designs included large trials that were randomized and double-blinded; randomized, open label; open label; crossover; and retrospective reports. Reports with small numbers of patients were included in Table 1 .

Table 1 also includes the history of chemotherapy administration because it can substantially influence the results of an antiemetic trial. Populations were consistent within studies in terms of patient gender, alcohol use, or exclusion criteria such as complaints of nausea or vomiting in the immediate period before chemotherapy was administered. Table 1 lists the number of patients included in each treatment arm.

Response rates in the table reflect complete responses, that is, no emetic episodes and no use of rescue medications. If a drug was reported to be statistically better, then it is noted in the column after complete response rates.

None of the randomized, double-blinded trials found a statistical difference in efficacy rates between granisetron and ondansetron. The studies with a lessrigid design also showed equivalency between the 2 agents, with a few exceptions. Yalcin et al. ${ }^{28}$ reported an advantage to using granisetron, $3 \mathrm{mg}$ intravenously, over ondansetron, $8 \mathrm{mg}$ intravenously, for moderately emetogenic chemotherapy. Study size was small at 18 or 19 patients per study arm. In a retrospective review of antiemetic therapy, Dempsey et al ${ }^{38}$ found that ondansetron, $8 \mathrm{mg}$ intravenously, was inferior to granisetron, $10 \mathrm{mcg} / \mathrm{kg}$ per dose. The study arms differed in that the ondansetron group was exposed to radiation more often, and corticosteroid use was less frequent in the ondansetron arm. Equivalent efficacy was also mostly reported in the setting of bone marrow transplants. The trial by Spitzer et al. ${ }^{16}$ showed a numerical superiority of granisetron over ondansetron, but the study arms were too small for statistical analysis. Lacerda et al..$^{20}$ observed that ondansetron, $24 \mathrm{mg} / \mathrm{d}$, was superior to granisetron, but that $16 \mathrm{mg} / \mathrm{d}$ of ondansetron was equivalent. Only 16 and 24 patients were included in the study arms for ondansetron, 16 $\mathrm{mg}$ and $24 \mathrm{mg}$, respectively.

For delayed emesis, efficacy was also similar among the first-generation 5-HT3 antagonists. A single dose of granisetron was reported by Stewart et al. ${ }^{11}$ to be less effective against delayed nausea than a multi-day regimen of ondansetron. An argument can be made that these were not equivalent doses. The period greater than 24 hours almost always showed less efficacy than the acute period.

In a meta-analysis of 14 studies and 6467 patients comparing ondansetron with granisetron in the prophylaxis of acute or delayed nausea and vomiting in the setting of highly emetogenic or moderately emetogenic chemotherapy, del Giglio et $a .^{48}$ showed an apparent equivalency between the 2 agents. Likewise, no significant differences in adverse effects occurred, except that patients receiving $32 \mathrm{mg}$ of ondansetron intravenously experienced blurred vision and dizziness more often. ${ }^{8}$ The more common side effects were headache, constipation, and diarrhea.

Dolasetron and ondansetron were compared in a trial for moderately emetogenic agents by Fauser et al. ${ }^{40}$ Dolasetron, $200 \mathrm{mg}$ orally, was equivalent to multiple doses of ondansetron, $8 \mathrm{mg}$. Audhuy et al. ${ }^{42}$ published a report showing intravenous granisetron and intravenous dolasetron to be equivalent in managing acute nausea and vomiting after treatment with highly emetogenic agents.

Palonosetron is a second-generation 5-HT3 antagonist. Three randomized, placebo-controlled, noninferiority trials compared this newer agent with first-generation 5-HT3 antagonists. Gralla et al. ${ }^{45} \mathrm{com}$ pared 2 dose levels of palonosetron with a single dose of ondansetron, $32 \mathrm{mg}$ intravenously, in the management of nausea and vomiting after treatment with moderately emetogenic chemotherapy in chemotherapy-naive and -non-naive patients not treated with steroids. Palonosetron, $0.25 \mathrm{mg}$ intravenously, was statistically better than ondansetron in both complete control of acute nausea and vomiting and delaying nausea and vomiting.

Palonosetron, $0.75 \mathrm{mg}$, was found to have no statistical difference from ondansetron. Aapro et al. ${ }^{46}$ studied palonosetron, $0.25 \mathrm{mg}$ intravenously and 0.75 $\mathrm{mg}$ intravenously, against ondansetron, $32 \mathrm{mg}$ intravenously, in both chemotherapy-naive and -non-naive patients with and without steroids undergoing highly emetogenic regimens. The 2 drugs showed no statistical difference either during the acute or the delayed phases.

Eisenberg et al..$^{47}$ compared dolasetron, $100 \mathrm{mg}$ intravenously, with palonosetron, $0.25 \mathrm{mg}$ intravenously and $0.75 \mathrm{mg}$ intravenously, after moderately emetogenic chemotherapy in chemotherapy-naive and -non-naive patients. A small percentage of patients

text continued on p. 5 
5-HT3 Receptor Antagonists

\begin{tabular}{|c|c|c|c|c|c|c|c|c|c|c|c|c|}
\hline Report & Drug & Regimen & Steroids & $\begin{array}{l}\text { Type of } \\
\text { Chemo- } \\
\text { therapy }\end{array}$ & $\begin{array}{l}\text { Study } \\
\text { Design }\end{array}$ & $\begin{array}{l}\text { Chemo } \\
\text { therapy- } \\
\text { Naïve }\end{array}$ & $N$ & $\begin{array}{l}\text { CR, } \\
\text { Acute }\end{array}$ & Result & $\begin{array}{l}\text { CR, } \\
\text { Delayed }\end{array}$ & Result & Comment \\
\hline $\begin{array}{l}\text { Forni } \\
\text { et al. }{ }^{4}\end{array}$ & Gra & $\begin{array}{l}2 \mathrm{mg} / \mathrm{m}^{2} / \mathrm{d} \\
\times 3 \mathrm{IV}\end{array}$ & No & High, MD & RN, DB & $100 \%$ & 30 & $62.90 \%$ & NS & & & \\
\hline 2000 & Ond & $\begin{array}{l}5.3 \mathrm{mg} / \mathrm{m}^{2} / \\
\mathrm{d} \times 3 \mathrm{IV}\end{array}$ & No & High, MD & & $100 \%$ & 30 & $58.30 \%$ & & & & \\
\hline $\begin{array}{l}\text { Barrajon } \\
\text { and de } \\
\text { las Penas } \\
2000\end{array}$ & $\begin{array}{l}\text { Gra } \\
\text { Ond }\end{array}$ & $\begin{array}{l}3 \mathrm{mg} \mathrm{IV} \\
24 \mathrm{mg} \text { IV }\end{array}$ & $\begin{array}{l}\text { Yes } \\
\text { Yes }\end{array}$ & $\begin{array}{l}\text { High } \\
\text { High }\end{array}$ & $\mathrm{RN}, \mathrm{DB}, \mathrm{C}$ & $\begin{array}{l}47 \% \\
61 \%\end{array}$ & $\begin{array}{l}40 \\
40\end{array}$ & $\begin{array}{l}43 \% \\
50 \%\end{array}$ & NS & & & \\
\hline $\begin{array}{l}\text { Gralla } \\
\text { et al. } \\
1998\end{array}$ & $\begin{array}{l}\text { Gra } \\
\text { Ond }\end{array}$ & $\begin{array}{l}2 \mathrm{mg} P O \\
32 \mathrm{mg} \text { IV }\end{array}$ & $\begin{array}{l}58.80 \% \\
61.50 \%\end{array}$ & High & $\mathrm{RN}, \mathrm{DB}$ & $100 \%$ & $\begin{array}{l}534 \\
520\end{array}$ & $\begin{array}{l}54.70 \% \\
58.30 \%\end{array}$ & NS & & & \\
\hline $\begin{array}{l}\text { Poon and } \\
\text { Chow }^{7} \\
1998\end{array}$ & $\begin{array}{l}\text { Gra } \\
\text { Ond }\end{array}$ & & $\begin{array}{l}\text { No } \\
\text { No }\end{array}$ & $\begin{array}{l}\text { Mod } \\
\text { Mod }\end{array}$ & $\mathrm{RN}, \mathrm{DB}, \mathrm{C}$ & $\begin{array}{l}\text { No } \\
\text { No }\end{array}$ & $\begin{array}{l}20 \\
20\end{array}$ & $\begin{array}{l}37 \% \\
35 \%\end{array}$ & NS & $\begin{array}{l}28 \% \\
25 \%\end{array}$ & NS & \\
\hline $\begin{array}{l}\text { Perez } \\
\text { et al. }{ }^{8} \\
1998\end{array}$ & $\begin{array}{l}\text { Gra } \\
\text { Ond }\end{array}$ & $\begin{array}{l}10 \mathrm{mcg} / \mathrm{kg} \\
\mathrm{IV} \\
32 \mathrm{mg} \mathrm{IV}\end{array}$ & $79.80 \%$ & Mod & $\mathrm{RN}, \mathrm{DB}, \mathrm{C}$ & $100 \%$ & 312 & $\begin{array}{l}58.6 \% \\
62.7 \%\end{array}$ & NS & $\begin{array}{l}27 \% \\
31 \%\end{array}$ & NS & $\begin{array}{l}\text { Ond: more } \\
\text { vision Sx }\end{array}$ \\
\hline $\begin{array}{l}\text { Perez } \\
\text { et al. } \\
1998\end{array}$ & $\begin{array}{l}\text { Gra } \\
\text { Ond }\end{array}$ & $\begin{array}{l}2 \mathrm{mg} P O \\
32 \mathrm{mg} \mathrm{IV}\end{array}$ & $\begin{array}{l}81.40 \% \\
81.60 \%\end{array}$ & $\begin{array}{l}\text { Mod } \\
\text { Mod }\end{array}$ & $\mathrm{RN}, \mathrm{DB}$ & $\begin{array}{l}100 \% \\
100 \%\end{array}$ & $\begin{array}{l}542 \\
543\end{array}$ & $\begin{array}{l}59.4 \% \\
58.0 \%\end{array}$ & NS & $\begin{array}{l}47 \% \\
44 \%\end{array}$ & NS & $\begin{array}{l}\text { Ond: more } \\
\text { vision Sx }\end{array}$ \\
\hline $\begin{array}{l}\text { Italian } \\
\text { Group }^{10} \\
1995\end{array}$ & $\begin{array}{l}\text { Gra } \\
\text { Ond }\end{array}$ & $\begin{array}{l}3 \mathrm{mg} \mathrm{IV} \\
8 \mathrm{mg} \mathrm{IV}\end{array}$ & $\begin{array}{l}\text { Yes } \\
\text { Yes }\end{array}$ & $\begin{array}{l}\text { High } \\
\text { High }\end{array}$ & RN, DB & $\begin{array}{l}100 \% \\
100 \%\end{array}$ & $\begin{array}{l}483 \\
483\end{array}$ & $\begin{array}{l}72 \% \\
72.0 \%\end{array}$ & NS & $\begin{array}{l}50 \% \\
53 \%\end{array}$ & NS & \\
\hline $\begin{array}{l}\text { Stewart } \\
\text { et al. }{ }^{11}\end{array}$ & Gra & $\begin{array}{l}3 \mathrm{mg} \\
\mathrm{IV} \times 1\end{array}$ & No & Mod & RN, DB & No & 166 & $54 \%$ & NS & $25 \%$ & Ond & \\
\hline \multirow[t]{2}{*}{1995} & Ond & $\begin{array}{l}8 \mathrm{mg} \mathrm{IV} \mathrm{+} \\
8 \mathrm{mg} \mathrm{PO} \\
\text { bid } \times 8\end{array}$ & No & Mod & & No & 167 & $51.0 \%$ & & $33 \%$ & & \\
\hline & Ond & $\begin{array}{l}8 \mathrm{mg} \text { PO } \\
\text { bid } \times 9\end{array}$ & No & Mod & & No & 155 & 55 & & $34 \%$ & & \\
\hline $\begin{array}{l}\text { Navari } \\
\text { et al. }{ }^{12}\end{array}$ & Gra & $\begin{array}{l}10 \mathrm{mcg} / \mathrm{kg} \\
\text { IV }\end{array}$ & No & High & $\mathrm{RN}, \mathrm{DB}$ & $100 \%$ & 328 & $38 \%$ & NS & & & \\
\hline \multirow[t]{2}{*}{1995} & Gra & $\begin{array}{l}40 \mathrm{mcg} / \mathrm{kg} \\
\text { IV }\end{array}$ & & & & & 328 & $41 \%$ & & & & \\
\hline & Ond & $\begin{array}{l}0.15 \mathrm{mg} / \mathrm{kg} \\
\mathrm{q} 4 \mathrm{~h} \times 3 \mathrm{IV}\end{array}$ & & & & & 331 & $39 \%$ & & & & \\
\hline $\begin{array}{l}\text { Huc } \\
\text { et al. }{ }^{13}\end{array}$ & Gra & 1 mg PO bid & $\begin{array}{l}\text { As chemo- } \\
\text { therapy }\end{array}$ & Mod & RN, O, C & $100 \%$ & 188 & $>50 \%$ & NS & & & \\
\hline 1998 & Ond & $8 \mathrm{mg}$ PO bid & & & & & & $>50 \%$ & & & & \\
\hline $\begin{array}{l}\text { Jantunen } \\
\text { et al. }{ }^{14}\end{array}$ & Gra & $3 \mathrm{mg} \mathrm{IV}$ & $\begin{array}{l}\text { As chemo- } \\
\text { therapy }\end{array}$ & Mod & $\mathrm{RN}, \mathrm{O}, \mathrm{C}$ & No & 92 & $80 \%$ & NS & & & \\
\hline 1993 & Ond & $8 \mathrm{mg} \mathrm{IV}$ & & & & & & $69 \%$ & & & & \\
\hline $\begin{array}{l}\text { Fox-Geiman } \\
\text { et al. }{ }^{15}\end{array}$ & Gra & $\begin{array}{l}1 \mathrm{mg} P O \\
\mathrm{q} 12 \mathrm{~h}\end{array}$ & Yes & High, MD & RN, DB & No & 34 & $90 \%$ & NS & $47 \%$ & NS & BMT \\
\hline 2001 & $\begin{array}{l}\text { Ond } \\
\text { Ond }\end{array}$ & $\begin{array}{l}32 \mathrm{mg} \\
\text { IV qd } \\
8 \mathrm{mg} P O \mathrm{q} 8 \mathrm{~h}\end{array}$ & $\begin{array}{l}\text { Yes } \\
\text { Yes }\end{array}$ & $\begin{array}{l}\text { High, MD } \\
\text { High, MD }\end{array}$ & & $\begin{array}{l}\text { No } \\
\text { No }\end{array}$ & $\begin{array}{l}34 \\
34\end{array}$ & $\begin{array}{l}90 \% \\
95 \%\end{array}$ & & $\begin{array}{l}49 \% \\
48 \%\end{array}$ & & $\begin{array}{l}\text { 8-day } \\
\text { period }\end{array}$ \\
\hline $\begin{array}{l}\text { Spitzer } \\
\text { et al. }^{16} \\
2000\end{array}$ & $\begin{array}{l}\text { Gra } \\
\text { Ond }\end{array}$ & $\begin{array}{l}2 \mathrm{mg} \mathrm{PO} \mathrm{qd} \\
8 \mathrm{mg} \text { PO q8h }\end{array}$ & No & TBI & $\mathrm{RN}, \mathrm{DB}$ & No & $\begin{array}{l}18 \\
16\end{array}$ & $\begin{array}{l}44.4 \% \\
26.7 \%\end{array}$ & & $\begin{array}{l}27.8 \% \\
26.7 \%\end{array}$ & & $\begin{array}{l}\text { BMT } \\
\text { 4-day } \\
\text { period }\end{array}$ \\
\hline $\begin{array}{l}\text { Orchard } \\
\text { et al. } .^{7}\end{array}$ & Gra & $\begin{array}{l}7.5-10 \mathrm{mcg} / \\
\mathrm{kg} \mathrm{q} 12 \mathrm{~h} \text { IV }\end{array}$ & Yes & $\begin{array}{l}\text { TBI/High, } \\
\text { MD }\end{array}$ & RN, DB & No & 90 & & NS & $\begin{array}{l}0.73 \\
/ \text { day* }\end{array}$ & & ВMT \\
\hline 1999 & Ond & $\begin{array}{l}8 \mathrm{mg} \text { LD, } \\
1 \mathrm{mg} / \mathrm{h} \mathrm{IV}\end{array}$ & & & $\begin{array}{l}\text { Pediatric/ } \\
\text { Adults }\end{array}$ & & 97 & & & $\begin{array}{l}0.86 / \\
\text { day* }\end{array}$ & & $\begin{array}{l}\text { 4-day } \\
\text { period }\end{array}$ \\
\hline $\begin{array}{l}\text { Slaby } \\
\text { et al. }{ }^{18}\end{array}$ & Gra & $\begin{array}{l}3 \mathrm{mg} \mathrm{IV} \\
\mathrm{qd} \times 6\end{array}$ & & High, MD & RN, O & No & 15 & $87 \%$ & NS & & & BMT \\
\hline 2000 & Ond & $\begin{array}{l}8 \mathrm{mg} \text { IV } \\
\text { bid } \times 6 \text { days }\end{array}$ & & High, MD & & No & 15 & $67 \%$ & & Day 4 & & \\
\hline
\end{tabular}


McNulty

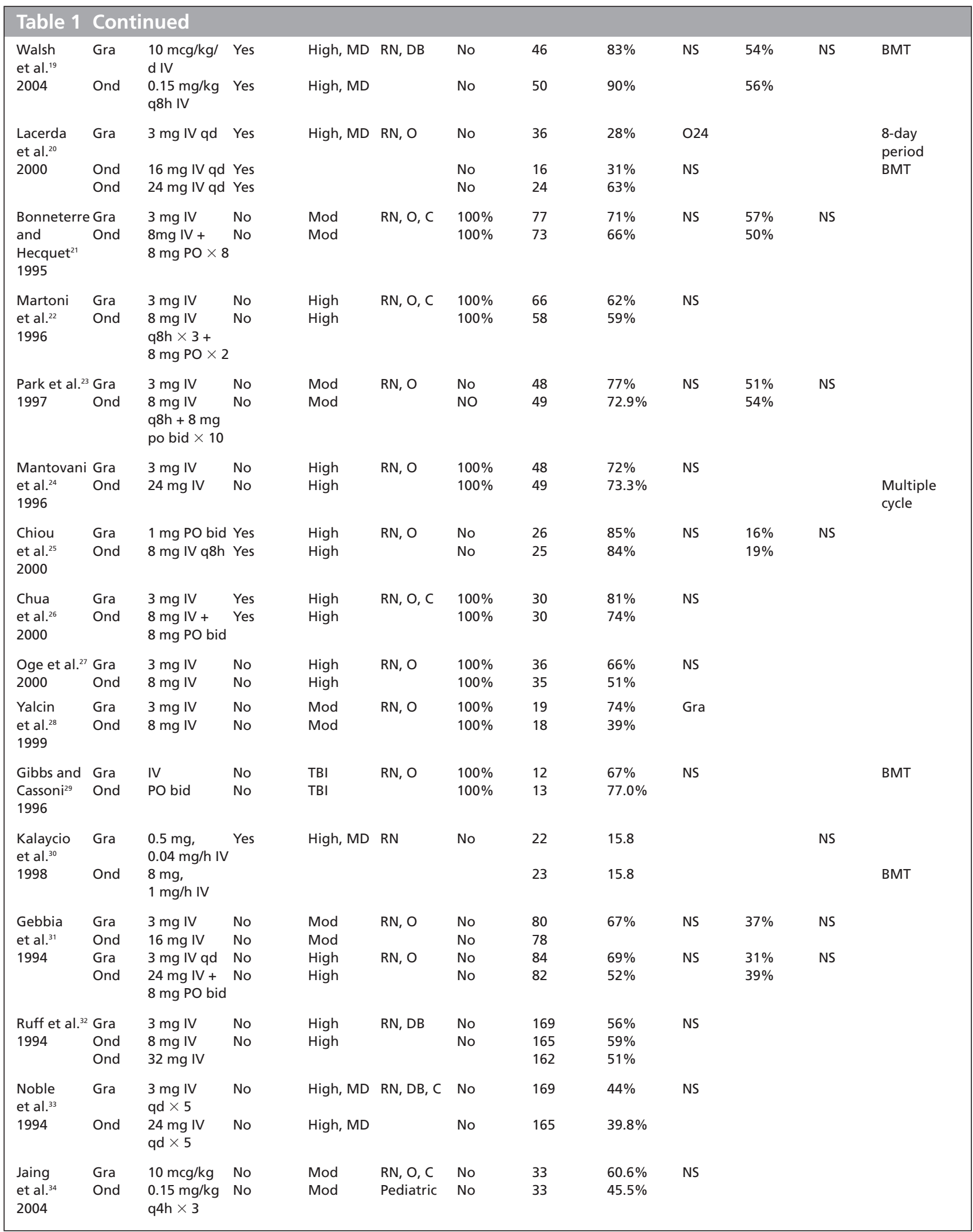


5-HT3 Receptor Antagonists

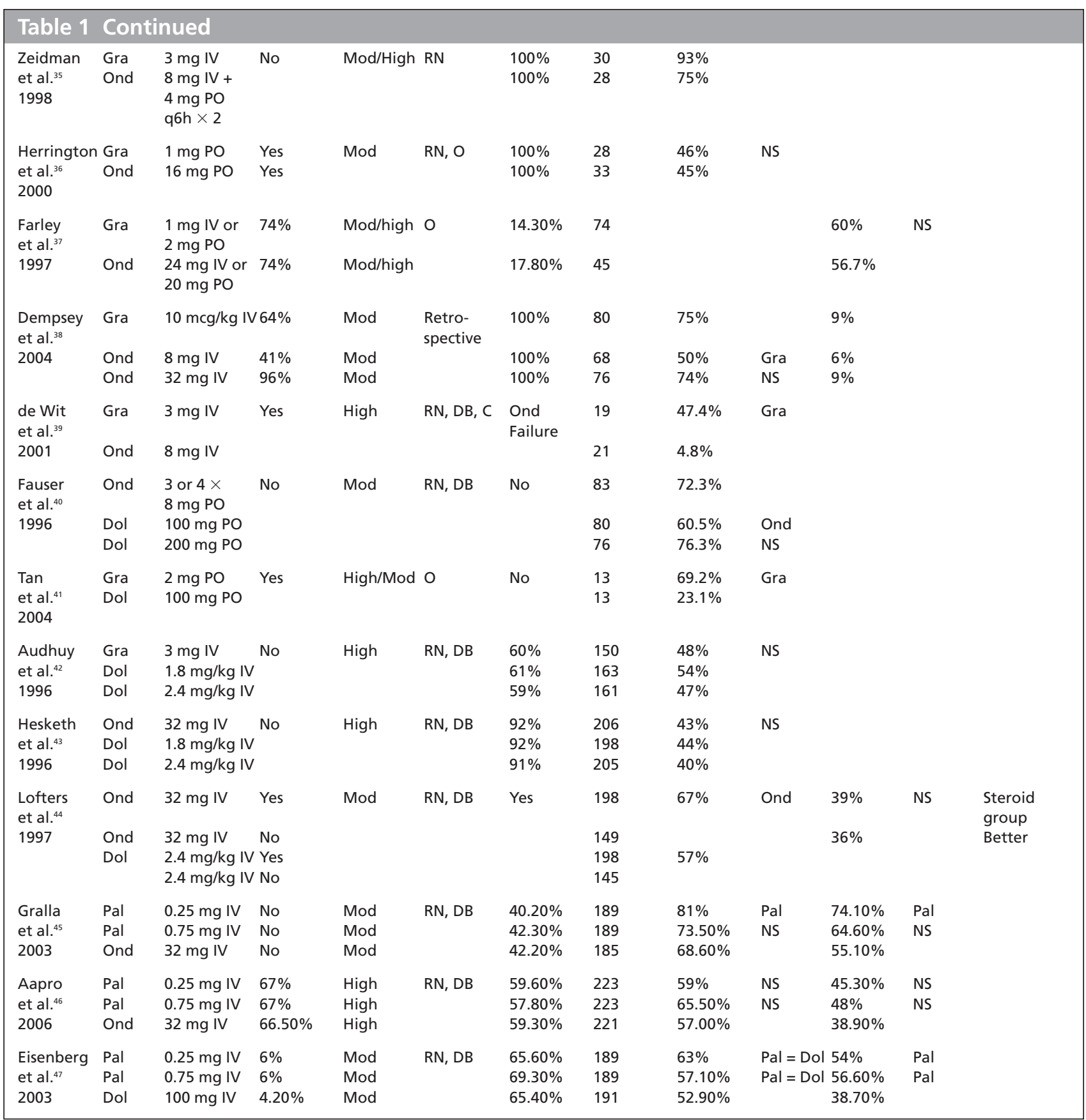

Abbreviations: *, number of episodes vomiting per day; bid, twice a day; BMT, bone marrow transplant; $C$, crossover design; CR, no episode of vomiting, no rescue medicine for nausea; DB, double-blinded; Dol, dolasetron; Gra, granisetron; High, highly emetogenic chemotherapy; IV, intravenous; MD, multiday regimen; Mod, moderately emetogenic chemotherapy; NS, not significant; O, open; Ond, ondansetron; Pal, palonosetron; PO, by mouth; q, every; RN, randomized; Sx, symptoms; TBI, total body irradiation.

text continued from p. 2

were treated with steroids. For the acute control of nausea and vomiting, palonosetron was not found to be inferior to dolasetron. For delayed nausea and vomiting, palonosetron was superior to dolasetron in preventing symptoms.

Data are emerging on multiday use of palonosetron. Hunt et al. ${ }^{49}$ reported on the safety of 3-day therapy 
McNulty

with palonosetron in normal subjects. Brames et al..$^{50}$ used dexamethasone daily and palonosetron on days 1 , 3 , and 5 of fractionated cisplatin therapy (bleomycin and etoposide or etoposide alone) for testicular cancer and found the therapy to be at least as effective and safe as historical controls involving ondansetron.

Palonosetron is at least as effective as first-generation 5-HT3 antagonists against acute nausea and vomiting. The primary goal of the above trials was to prove noninferiority of palonosetron to the first-generation 5-HT3 antagonists, and that goal was achieved. No trials have been designed to prove the superiority of palonosetron over other agents in its class. The comparative efficacy of palonosetron against delayed nausea and vomiting cannot be fully determined until trials have been conducted with other agents dosed appropriately to provide a pharmacologic effect throughout the study period, including the acute and delayed phases.

Steroids and aprepitant have emerged as the favored agents to prevent nausea and vomiting in the delayed phase after highly emetogenic chemotherapy. The current recommended antiemetic treatment strategies for moderately and highly emetogenic chemotherapy use combinations of 5-HT3 antagonists, steroids, and aprepitant. ${ }^{1,2}$ As the 2006 ASCO guidelines ${ }^{2}$ point out, "The superiority question has now evolved to whether or not palonosetron is better than other 5-HT3 antagonists when they are combined with both dexamethasone and aprepitant."

At equivalent doses, the 5-HT3 antagonists may be judged as similar in efficacy and safety, and other factors, such as cost or convenience, can be considered in choosing between them. These agents have pharmacologic differences in terms of absorption, half-life, receptor-binding affinity, selectivity of binding sites, and metabolism (Table 2). Bioavailability for the first- generation 5-HT3 antagonists allows for oral administration. Palonosetron is unlikely to be available orally because of extensive first-pass effect. As the results of the clinical trials indicate, oral administration of the other agents has similar efficacy.

Despite the shorter half-life seen with ondansetron, all of the first-generation 5-HT3 antagonists seem to able to be administered daily with similar efficacy, suggesting a dissociation of duration of action from half-life. Ondansetron has displayed activity at various receptors other than 5 -HT3 receptors. These include 5-HT1A, 5-HT1B, $\alpha 1$-adrenergic, and $\mu$-opioid receptors. Palonosetron also binds to 5-HT $\alpha 1 \mathrm{~A}, 5$-HT1A, 5-HT1D, 5-HT2A, 5-HT2C, muscarinic $\mathrm{M}_{2}$ and $\kappa$ - and $\delta$-opiod receptors. Obvious differences in the incidence of adverse effect related to these additional binding sites have not been reported consistently in the clinical trials.

The primary metabolic pathway for ondansetron is hydroxylation on the indole ring followed by glucuronide or sulfate conjugation, with some nonconjugated active metabolites. Granisetron metabolism involves $\mathrm{N}$-demethylation and aromatic ring oxidation followed by conjugation. Some metabolites may also have 5 -HT3 receptor antagonist activity.

Dolasetron is reduced to hydrodolasetron by a ubiquitous enzyme, carbonyl reductase. CYP2D6 is primarily responsible for the subsequent hydroxylation of hydrodolasetron and both CPT3A and flavin monooxygenase are responsible for $\mathrm{N}$-oxidation of hydrodolasetron. Palonosetron is metabolized to $\mathrm{N}$-oxide-palonosetron and 6-S-hydroxy-palonosetron. Metabolites have very weak antagonist activity. CYP2D6 and, to a lesser extent, CYP3A and CYP1A2 are involved in metabolizing palonosetron. Kinetic parameters of palonosetron are not significantly different between poor and extensive metabolizers of

\begin{tabular}{|c|c|c|c|c|}
\hline Drug & $\begin{array}{l}\text { Oral } \\
\text { Bioavailability }\end{array}$ & $\begin{array}{l}\text { Half-life } \\
\text { (h) }\end{array}$ & $\begin{array}{l}\text { Receptor Binding } \\
\text { Affinity }\end{array}$ & Enzymes Involved in Metabolism \\
\hline $\begin{array}{l}\text { Dolasetron } \\
\text { (hydrodolasetron) }\end{array}$ & $75 \%$ & 7.3 & $9.8\left(\mathrm{PA}_{2}\right)$ & $\begin{array}{l}\text { Carbonyl reductase, CYP2D6*, } \\
\text { CYP3A, flavin monooxygenase }\end{array}$ \\
\hline Granisetron & $65 \%$ & $4.91-8.95$ & $8.42 \mathrm{pK}_{\mathrm{i}}$ & CYP3A \\
\hline Ondansetron & $56 \%$ & $3.5-5.5$ & $8.07 \mathrm{pK}_{\mathrm{i}}$ & CYP2D6, CYP3A4*, CYP1A2, CYP2E1 \\
\hline Palonesetron & 9\% (monkey) & 40 & $10.4 \mathrm{pK}_{\mathrm{i}}$ & CYP2D6*, CYP3A, CYP1A1 \\
\hline
\end{tabular}

*Dominant role

Abbreviations: $\mathrm{PA}_{2}$, comparative index of antagonism for $5-\mathrm{HT} 3$ receptor; $\mathrm{pK}_{\mathrm{i}}$, measure of the binding affinity of the test compound to the receptors present in the cell homogenate; CYP, human cytochrome P450. 
5-HT3 Receptor Antagonists

CYP2D6 substrates. The enzymes involved in metabolizing the 5-HT3 antagonists are listed in Table 2.

Metabolism does not appear to have a major influence on the results seen in clinical trials.

Ultrarapid metabolizers have been reported in association with CYP2D6. Kaiser et al. ${ }^{51}$ reported on CYP2D6 genotypes influencing emetic control after ondansetron use, showing that patients experiencing failed treatment with 5-HT3 antagonists may benefit from treatment with an agent not metabolized by CYP2D6. The incidence of ultra metabolizers is variable across different populations: Saudis 21\%, Ethiopians 18\%, Sephardic Jews 13\%, Italians 8\%, and Caucasians $1 \%$ to $8 \%{ }^{51}$ de Wit et al. ${ }^{39}$ rescued patients experiencing ondansetron failures who were undergoing highly emetogenic chemotherapy. In a randomized, double-blind study, either granisetron, 3 mg intravenously with dexamethasone, or ondansetron, $8 \mathrm{mg}$ intravenously with dexamethasone, was given on the second cycle. Compared with only $5 \%$ of the ondansetron group, $47 \%$ of the granisetron group experienced complete protection. de Wit et al. ${ }^{39}$ concluded that the presence of no cross-tolerance among 5-HT3 antagonists and the changing of medications within the class have significant potential to provide antiemetic efficacy. Whether differences in enzyme metabolism can fully explain a lack of cross tolerance is unknown.

\section{Summary}

Clinical trials support a policy of considering the 5-HT3 antagonists therapeutically similar in efficacy and safety. The minor differences in half-life, receptor binding, and metabolism may influence adaptations to a treatment plan but do not play a major role in the initial selection of a 5-HT3 antagonist.

\section{References}

1. Ettinger DS, Bierman PJ, Bradbury B, et al. The NCCN antiemesis clinical practice guidelines in oncology, version 2, 2006. Available at: http://www.nccn.org/professionals/physician_gls/PDF/antiemesis.pdf. Accessed July 30, 2006.

2. Kris MG, Hesketh PJ, Somerfield, MR, et al. American Society of Clinical Oncology guideline for antiemetics in oncology: update 2006. J Clin Oncol 2006;24:2932-2946.

3. Cancer Care Ontario: use of 5-HT3 receptor antagonists in patients receiving moderately or highly emetogenic chemotherapy, 2003. Available at: http://www.cancercare.on.ca/pdf/pebc12_3f.pdf. Accessed October 28, 2006.
4. Forni C, Ferrari S, Loro L, et al. Granisetron, tropisetron, and ondansetron in the prevention of acute emesis induced by a combination of cisplatin-Adriamycin and by high-dose ifosfamide delivered in multiple-day continuous infusions. Support Care Cancer 2000; 8:131-133.

5. Barrajon E, de las Penas R. Randomised double blind crossover study comparing ondansetron, granisetron and tropisetron. A cost-benefit analysis. Support Care Cancer 2000;8:323-333.

6. Gralla RJ, Navari RM, Hesketh PJ, et al. Single-dose oral granisetron has equivalent antiemetic efficacy to intravenous ondansetron for highly emetogenic cisplatin-based chemotherapy. J Clin Oncol 1998;16:1568-1573.

7. Poon RT, Chow LW. Comparison of antiemetic efficacy of granisetron and ondansetron in Oriental patients: a randomized crossover study. Br J Cancer 1998;77:1683-1685.

8. Perez EA, Lembersky B, Kaywin P, et al. Comparable safety and antiemetic efficacy of a brief (30-second bolus) intravenous granisetron infusion and a standard (15-minute) intravenous ondansetron infusion in breast cancer patients receiving moderately emetogenic chemotherapy. Cancer J Sci Am 1998;4:52-58.

9. Perez EA, Hesketh P, Sandbach J, et al. Comparison of single-dose oral granisetron versus intravenous ondansetron in the prevention of nausea and vomiting induced by moderately emetogenic chemotherapy: a multicenter, double-blind, randomized parallel study. J Clin Oncol 1998;16:754-760.

10. Italian Group of Antiemetic Research. Ondansetron versus granisetron, both combined with dexamethasone, in the prevention of cisplatin-induced emesis. Ann Oncol 1995;6:805-810.

11. Stewart A, McQuade B, Cronje JD, et al. Ondansetron compared with granisetron in the prophylaxis of cyclophosphamide-induced emesis in out-patients: a multicentre, double-blind, double-dummy, randomised, parallel-group study. Emesis Study Group for Ondansetron and Granisetron in Breast Cancer Patients. Oncology 1995;52:202-210.

12. Navari R, Gandara D, Hesketh $P$, et al. Comparative clinical trial of granisetron and ondansetron in the prophylaxis of cisplatin-induced emesis. The Granisetron Study Group. J Clin Oncol 1995; 13:1242-1248.

13. Huc P, Block S, Carlier D, et al. [Granisetron (per os) compared with ondansetron (per os) in the prevention of nausea and vomiting induced by mildly emetogenic chemotherapies. Groupe de Recherches en Cancerologie du Nord]. Bull Cancer 1998;85:562-568 [in French].

14. Jantunen IT, Muhonen TT, Kataja VV, et al. 5-HT3 receptor antagonists in the prophylaxis of acute vomiting induced by moderately emetogenic chemotherapy - a randomised study. Eur J Cancer 1993;29A:1669-1672.

15. Fox-Geiman MP, Fisher SG, Kiley K, et al. Double-blind comparative trial of oral ondansetron versus oral granisetron versus IV ondansetron in the prevention of nausea and vomiting associated with highly emetogenic preparative regimens prior to stem cell transplantation. Biol Blood Marrow Transplant 2001;7:596-603.

16. Spitzer TR, Friedman CJ, Bushnell W, et al. Double blind, randomized, parallel-group study on the efficacy and safety of oral granisetron and oral ondansetron in the prophylaxis of nausea and vomiting in patients receiving hyperfractionated total body irradiation. Bone Marrow Transplant 2000;26:203-210.

17. Orchard PJ, Rogosheske J, Burns L, et al. A prospective randomized trial of the anti-emetic efficacy of ondansetron and granisetron during bone marrow transplantation. Biol Blood Marrow Transplant 1999;5:386-393. 
McNulty

18. Slaby J, Trneny M, Prochazka B, et al. Antiemetic efficacy of three serotonin antagonists during high-dose chemotherapy and autologous stem cell transplantation in malignant lymphoma. Neoplasma 2000;47:319-322.

19. Walsh T, Morris AK, Holle LM, et al. Granisetron vs ondansetron for prevention of nausea and vomiting in hematopoietic stem cell transplant patients: results of a prospective, double-blind, randomized trial. Bone Marrow Transplant 2004;34:963-968.

20. Lacerda JF, Martins C, Carmo JA, et al. Randomized trial of ondansetron, granisetron, and tropisetron in the prevention of acute nausea and vomiting. Transplant Proc 2000;32:2680-2681.

21. Bonneterre J, Hecquet B. Granisetron (IV) compared with ondansetron (IV plus oral) in the prevention of nausea and vomiting induced by moderately-emetogenic chemotherapy. A cross-over study. Bull Cancer 1995;82:1038-1043.

22. Martoni A, Angelelli B, Guaraldi M, et al. An open randomised cross-over study on granisetron versus ondansetron in the prevention of acute emesis induced by moderate dose cisplatin-containing regimens. Eur J Cancer 1996;32A:82-85.

23. Park JO, Rha SY, Yoo NC, et al. A comparative study of intravenous granisetron versus intravenous and oral ondansetron in the prevention of nausea and vomiting associated with moderately emetogenic chemotherapy. Am J Clin Oncol 1997;20:569-572.

24. Mantovani G, Maccio A, Curreli L, et al. Comparison of oral 5-HT3-receptor antagonists and low-dose oral metoclopramide plus i.m. dexamethasone for the prevention of delayed emesis in head and neck cancer patients receiving high-dose cisplatin. Oncol Rep 1998;5:273-280.

25. Chiou TJ, Tzeng WF, Wang WS, et al. Comparison of the efficacy and safety of oral granisetron plus dexamethasone with intravenous ondansetron plus dexamethasone to control nausea and vomiting induced by moderate/severe emetogenic chemotherapy. Zhonghua Yi Xue Za Zhi (Taipei) 2000;63:729-736.

26. Chua DT, Sham JS, Kwong DL, et al. Comparative efficacy of three 5-HT3 antagonists (granisetron, ondansetron, and tropisetron) plus dexamethasone for the prevention of cisplatin-induced acute emesis: a randomized crossover study. Am J Clin Oncol 2000;23:185-191.

27. Oge A, Alkis N, Oge $\mathrm{O}$, et al. Comparison of granisetron, ondansetron and tropisetron for control of vomiting and nausea induced by cisplatin. J Chemother 2000;12:105-108.

28. Yalcin $S$, Tekuzman $G$, Baltali E, et al. Serotonin receptor antagonists in prophylaxis of acute and delayed emesis induced by moderately emetogenic, single-day chemotherapy: a randomized study. Am J Clin Oncol 1999;22:94-96.

29. Gibbs SJ, Cassoni AM. A pilot study to evaluate the cost-effectiveness of ondansetron and granisetron in fractionated total body irradiation. Clin Oncol (R Coll Radiol) 1996;8:182-184.

30. Kalaycio M, Mendez Z, Pohlman B, et al. Continuous-infusion granisetron compared to ondansetron for the prevention of nausea and vomiting after high-dose chemotherapy. J Cancer Res Clin Oncol 1998;124:265-269.

31. Gebbia V, Cannata G, Testa A, et al. Ondansetron versus granisetron in the prevention of chemotherapy-induced nausea and vomiting. Results of a prospective randomized trial. Cancer 1994;74:1945-1952.

32. Ruff P, Paska W, Goedhals L, et al. Ondansetron compared with granisetron in the prophylaxis of cisplatin-induced acute emesis: a multicentre double-blind, randomised, parallel-group study. The Ondansetron and Granisetron Emesis Study Group. Oncology 1994;51:113-118.
33. Noble A, Bremer K, Goedhals L, et al. A double-blind, randomised, crossover comparison of granisetron and ondansetron in 5-day fractionated chemotherapy: assessment of efficacy, safety and patient preference. The Granisetron Study Group. Eur J Cancer 1994;30A: $1083-1088$.

34. Jaing TH, Tsay PK, Hung IJ, et al. Single-dose oral granisetron versus multidose intravenous ondansetron for moderately emetogenic cyclophosphamide-based chemotherapy in pediatric outpatients with acute lymphoblastic leukemia. Pediatr Hematol Oncol 2004;21: 227-235.

35. Zeidman A, Ben Dayan D, Ben Zion T, et al. Granisetron and ondansetron for chemotherapy-related nausea and vomiting. Haematologia (Budap) 1998;29:25-31.

36. Herrington JD, Kwan P, Young RR, et al. Randomized, multicenter comparison of oral granisetron and oral ondansetron for emetogenic chemotherapy. Pharmacotherapy 2000;20:1318-1323.

37. Farley PA, Dempsey CL, Shillington AA, et al. Patients' self-reported functional status after granisetron or ondansetron therapy to prevent chemotherapy-induced nausea and vomiting at six cancer centers. Am J Health Syst Pharm 1997;54:2478-2482.

38. Dempsey CL, Coop AJ, Shillington A, et al. Antiemetic effectiveness of ondansetron and granisetron in patients with breast cancer treated with cyclophosphamide. Am J Health Syst Pharm 2004; 61:781-786.

39. de Wit R, de Boer AC, vd Linden GH, et al. Effective cross-over to granisetron after failure to ondansetron, a randomized double blind study in patients failing ondansetron plus dexamethasone during the first 24 hours following highly emetogenic chemotherapy. Br J Cancer 2001;85:1099-1101.

40. Fauser AA, Duclos B, Chemaissani A, et al. Therapeutic equivalence of single oral doses of dolasetron mesilate and multiple doses of ondansetron for the prevention of emesis after moderately emetogenic chemotherapy. European Dolasetron Comparative Study Group. Eur J Cancer 1996;32A:1523-1529.

41. Tan $M, X u R$, Seth R. Granisetron vs dolasetron for acute chemotherapy-induced nausea and vomiting (CINV) in high and moderately high emetogenic chemotherapy: an open-label pilot study. Curr Med Res Opin 2004;20:879-882.

42. Audhuy B, Cappelaere $\mathrm{P}$, Martin M, et al. A double-blind, randomised comparison of the anti-emetic efficacy of two intravenous doses of dolasetron mesilate and granisetron in patients receiving high dose cisplatin chemotherapy. Eur J Cancer 1996;32A:807-813.

43. Hesketh $\mathrm{P}$, Navari R, Grote T, et al. Double-blind, randomized comparison of the antiemetic efficacy of intravenous dolasetron mesylate and intravenous ondansetron in the prevention of acute cisplatin-Induced emesis in patients with cancer. Dolasetron Comparative Chemotherapy-Induced Emesis Prevention Group. J Clin Oncol 1996;14:2242-2249.

44. Lofters WS, Pater JL, Zee B, et al. Phase III double-blind comparison of dolasetron mesylate and ondansetron and an evaluation of the additive role of dexamethasone in the prevention of acute and delayed nausea and vomiting due to moderately emetogenic chemotherapy. J Clin Oncol 1997;15:2966-2973.

45. Gralla R, Lichinitser M, Van Der Vegt S, et al. Palonosetron improves prevention of chemotherapy-induced nausea and vomiting following moderately emetogenic chemotherapy: results of a doubleblind randomized phase III trial comparing single doses of palonosetron with ondansetron. Ann Oncol 2003;14:1570-1577.

46. Aapro MS, Grunberg, SM, Manikhas GM, et al. A phase III, double-blind, randomized trial of palonosetron compared with ondansetron in preventing chemotherapy-induced nausea and vomiting 
5-HT3 Receptor Antagonists

following highly emetogenic chemotherapy. Ann Oncol 2006; 17:1441-1449.

47. Eisenberg P, Figueroa-Vadillo J, Zamora R, et al. Improved prevention of moderately emetogenic chemotherapy-induced nausea and vomiting with palonosetron, a pharmacologically novel 5-HT3 receptor antagonist: results of a phase III, single-dose trial versus dolasetron. Cancer 2003;98:2473-2482.

48. del Giglio A, Soares HP, Caparroz C, et al. Granisetron is equivalent to ondansetron for prophylaxis of chemotherapy-induced nausea and vomiting: results of a meta-analysis of randomized controlled trials. Cancer 2000;89:2301-2308.
49. Hunt TL, Gallagher SC, Cullen MT Jr, et al. Evaluation of safety and pharmacokinetics of consecutive multiple-day dosing of palonosetron in healthy subjects. J Clin Pharmacol 2005;45:589-596.

50. Brames MJ, Roth BJ, Dreicer R, et al. Palonosetron + dexamethasone for prevention of chemotherapy-induced nausea and vomiting in patients receiving multiple-day cisplatin for germ cell cancer. Presented at the $42 \mathrm{nd}$ annual meeting of the American Society of Clinical Oncology. Atlanta, Georgia, June 2-6, 2006.

51. Kaiser R, Sezer O, Papies A, et al. Patient-tailored antiemetic treatment with 5-hydroxytryptamine type 3 receptor antagonists according to cytochrome P-450 2D6 genotypes. J Clin Oncol 2002;20:2805-2811. 